\title{
Effects of low and high salinity regimes on seasonal gametogenesis of the ribbed mussel Geukensia granosissima in coastal Louisiana, USA
}

\author{
Aaron Honig ${ }^{1}$, Megan La Peyre ${ }^{2, *}$, John Supan ${ }^{3}$ \\ ${ }^{1}$ School of Renewable Natural Resources, Louisiana State University Agricultural Center, Baton Rouge, LA 70803, USA \\ ${ }^{2}$ US Geological Survey, Louisiana Cooperative Fish and Wildlife Research Unit, School of Renewable Natural Resources, \\ Louisiana State University Agricultural Center, Baton Rouge, LA 70803, USA \\ ${ }^{3}$ Louisiana Sea Grant, Louisiana State University, Baton Rouge, LA 70803, USA
}

\begin{abstract}
The environmental controls on the reproductive timing of bivalves need to be better understood and documented in order to predict the potential consequences of a changing environment on bivalve populations. In order to determine the potential impacts of shifting salinity and temperature regimes along the northern Gulf of Mexico, the seasonal timing of gametogenesis in the Gulf estuarine ribbed mussel Geukensia granosissima was examined across a salinity gradient in south Louisiana, USA, from July 2011 through October 2012. Ten mussels were randomly sampled monthly from low $(\sim 7)$ and moderate $(\sim 17)$ salinity marsh sites in south Louisiana and histologically processed to determine the seasonal progression of gametogenesis. Mussels at both sites showed an extended period of maturity from early spring through late fall, when temperatures remained above $20^{\circ} \mathrm{C}$. Salinity affected the extent and timing of sexual maturity in the Gulf estuarine ribbed mussel, suggesting that changes in salinity regimes may impact long-term population dynamics.
\end{abstract}

KEY WORDS: Mussel $\cdot$ Reproduction $\cdot$ Temperature $\cdot$ Salinity $\cdot$ Louisiana $\cdot$ Salt marsh $\cdot$ Estuary

\section{INTRODUCTION}

The distribution of estuarine populations of benthic, sessile invertebrates is inherently dependent on the spatial and temporal frequencies of larval recruitment (Beukema \& Dekker 2007, Knights \& Walters 2010). The seasonal timing of gametogenesis and broadcast spawning events is critically important in determining larval output, juvenile settlement and subsequent adult density and distribution (Franz 1996). Spawning and larval development must coincide with available food resources and preferential currents for transport to desirable recruitment substrates while limiting exposure to high rates of daily predation mortality (Whitton et al. 2012). Understanding seasonal timing of gametogenesis and, specifically, understanding

${ }^{*}$ Corresponding author: mlapey@lsu.edu the effect of key environmental variables on this seasonal timing is a critical first step in predicting population dynamics of species.

Although identified as a likely distinct species from Guekensia demissa (Lee \& Foighil 2004, 2005), much of what is thought to be known about the Gulf estuarine ribbed mussel G. granosissima is derived from work on its Atlantic cousin, G. demissa. Gametogenesis of ribbed mussels along the Atlantic coast ( $G$. demissa) is generally characterized by gametogenesis leading to one distinct peak of spawning activity (Brousseau 1982, Borrero 1987). Increased summer temperatures have been strongly correlated with the onset of gametogenesis in ribbed mussels (Franz 1997) as well as in many other invertebrate taxa (Palmer 1980, Hackney 1983, Mladineo et al. 2007).

() Honig and Supan 2014. Open Access under Creative Commons by Attribution Licence. Use, distribution and reproduction are unrestricted. Authors and original publication must be credited. 
Recently introduced mussel populations (identified as G. demissa) within tropical marshes experiencing little seasonal temperature variation undergo an extended reproductive season, highlighted by 2 distinct peaks of spawning activity (Baez et al. 2005). While such marsh habitats are uniformly warm throughout the year, large fluctuations in ambient salinity occur during the onset of the tropical rainy season in midsummer and again during the extended dry season from midwinter through spring; these 2 changes are matched with 2 distinct spawning events (Baez et al. 2005). Similar reproductive timing has been observed across several tropical molluscan taxa (Puyana 1995, Ruiz et al. 1998), suggesting that seasonal shifts in salinity may also be an important determinant of gametogenesis in ribbed mussels.

The Barataria-Terrebonne estuarine system, Louisiana, USA, experiences temperatures ranging from 10 to $30^{\circ} \mathrm{C}$ (Feng \& Li 2010) and is subject to large salinity gradients from its headwaters near Mississippi River distributaries, south to the coastal barrier islands along the northern Gulf of Mexico (salinity range: 5-25, Wiseman et al. 1990, Inoue et al. 2008). As a result, in contrast to both temperate Atlantic marshes, which experience large seasonal temperature variation and low salinity variation, and tropical marshes, which experience large shifts in salinity and low variation in annual temperatures, ribbed mussels in Louisiana are subject to large seasonal fluctuations in both temperature and salinity. Furthermore, as Louisiana estuaries are shallow, wellmixed systems, temperatures tend to vary temporally and not spatially within the estuary, allowing us to test the effects of salinity on organism responses, with temperature varying consistently between sites.

This study documents the seasonal gametogenesis of ribbed mussels in the northern Gulf of Mexico. Specifically, this study explored the influence of temperature and salinity on observed patterns of reproductive maturation of ribbed mussels in Barataria-Terrebonne Bays, Louisiana. Results from this study may help explain patterns of spawning, juvenile recruitment, and subsequent population densities of ribbed mussels within coastal Louisiana. Such information would be useful in forecasting potential ecosystem impacts of ribbed mussel populations within southern coastal marshes, particularly with respect to predicted changes in temperature and salinity in the northern Gulf of Mexico from climate change and large-scale restoration projects.

\section{MATERIALS AND METHODS}

To determine the influence of salinity and temperature on the progression of gametogenesis in ribbed mussels, 10 individuals were randomly collected monthly from July 2011 to October 2012 at 2 sites. One site was located in the upper estuary with an annual mean salinity of $6.7 \pm 0.3$ (mean $\pm \mathrm{SE}$ ) (Cocodrie; $29^{\circ} 15^{\prime} 26.52^{\prime \prime} \mathrm{N}, 90^{\circ} 39^{\prime} 44.09^{\prime \prime} \mathrm{W}$ ), and the second site was located in the lower estuary with an annual mean salinity of $17.2 \pm 0.3$ (mean \pm SE) (Raccoon Lake; $29^{\circ} 17^{\prime} 46.11^{\prime \prime}$ N, 9001' 15.54" W). Salinity and temperature were recorded using continuous data recorders located at each site (Cocodrie: CRMS0369; Raccoon Lake: CRMS0178; CRMS, LOCPR 2012) (Fig. 1). Only individuals over $20 \mathrm{~mm}$ in length (measured from umbo to anterior shell margin) were selected because previous studies suggested that mussels smaller than $20 \mathrm{~mm}$ are incapable of sexual maturity (Borrero 1987, Franz 1996). Collected samples were transported on ice, stored at $5^{\circ} \mathrm{C}$ in the Louisiana State University Agricultural Center's Department of Veterinary Science and processed within $48 \mathrm{~h}$.

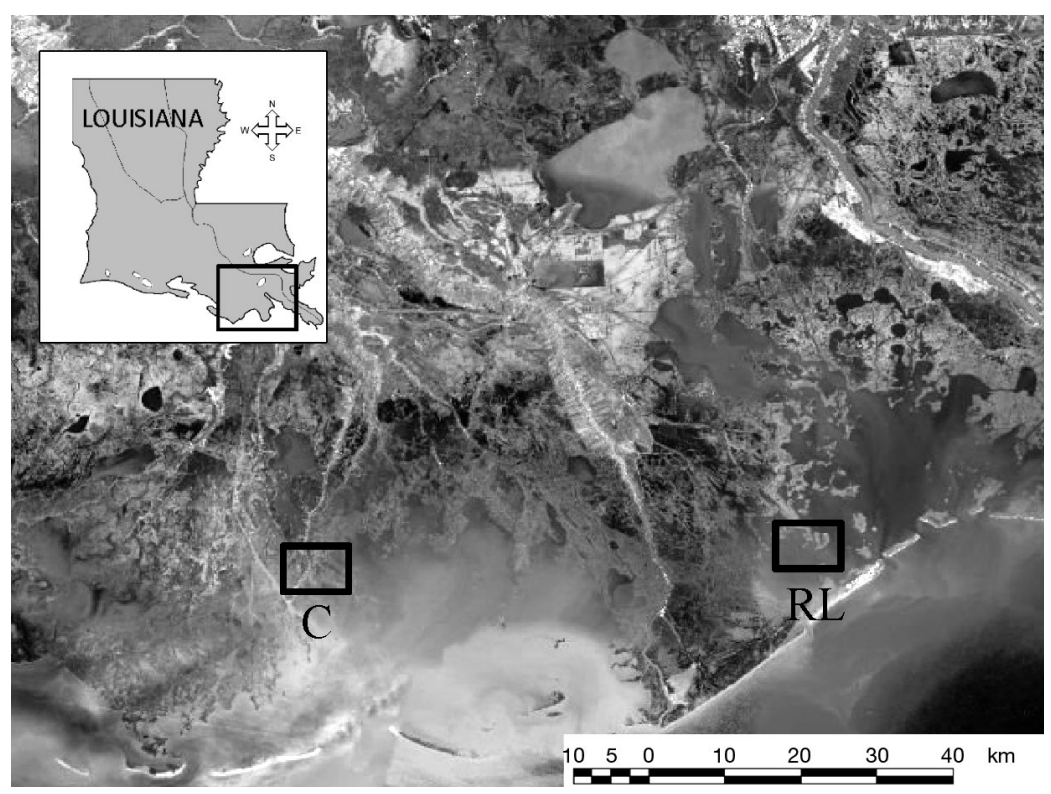

Fig. 1. Field sites within Louisiana estuaries. Geukensia granosissima mussels were collected in Cocodrie (C) and from Raccoon Lake (RL), LA, USA 
Histological observations of mantle and visceral mass tissues were used to determine sex and track progression of gametogenesis in sampled mussels following the methods of Cerwonka (1968) and Brousseau (1982). Stages of gametogenic development were determined by examination of histological preparations of excised visceral mass and mantle tissues as in Brousseau (1982). Reproductive tissues were removed, fixed in $10 \%$ formalin for $24 \mathrm{~h}$, and stored in $70 \%$ ethyl alcohol solution. Tissues were then prepared for histological analysis following the method described by Brousseau (1982). Five stages of gametogenesis were used for this analysis. The stages ranged from indifferent (Stage I), developing (Stage II), mature (Stage III), partially or postspawned (Stage IV) and spent (Stage V) and were defined as described by Brousseau (1982) (Table 1, Fig. 2). Within each sample month, mussels were identified as indeterminate sex, or male or female. If sex was determined, then gametogenic stages, Stages II-V, were assigned based on microscopic observa-

Table 1. Geukensia granosissima. Primary characteristics of the 5 stages used to classify the state of each mussel. Pictures depicting typical stages are shown in Fig. 2

\begin{tabular}{|c|c|}
\hline Stage & Primary characteristics \\
\hline I: indifferent & $\begin{array}{l}\text { - Sex indeterminate } \\
\text { - Follicles or spermatozoan aggregates } \\
\text { not observed }\end{array}$ \\
\hline $\begin{array}{l}\text { II: developing } \\
\text { Fig. } 2(\mathrm{~A}, \mathrm{~B})\end{array}$ & $\begin{array}{l}\text { - Small egg follicles or sparse clusters } \\
\text { of sperm cells present across female } \\
\text { follicles and spermatozoan clusters } \\
\text { - Follicles in both males and females } \\
\text { occupy a large part of the gonadal } \\
\text { tissue and mantle }\end{array}$ \\
\hline $\begin{array}{l}\text { III: mature } \\
\text { Fig. } 2 \\
(\mathrm{C}, \mathrm{D}, \mathrm{G})\end{array}$ & $\begin{array}{l}\text { - Mature spermatozoa with increased } \\
\text { volume and individual cells } \\
\text { arranged into bands with tails } \\
\text { pointing toward the center of the } \\
\text { lumen in males } \\
\text { - Large, round oocytes with some } \\
\text { attached to the follicular wall; others } \\
\text { appearing as free oocytes } \\
\text { - Nucleolus within the nucleus for males } \\
\text { and females }\end{array}$ \\
\hline $\begin{array}{l}\text { IV: partially } \\
\text { or post- } \\
\text { spawned } \\
\text { Fig. } 2(\mathrm{E}, \mathrm{H})\end{array}$ & $\begin{array}{l}\text { - Marked decrease in the number of } \\
\text { spermatozoa with most follicles } \\
\text { empty or follicles emptying in males } \\
\text { - Noticeable reduction in the number of } \\
\text { mature oocytes in females }\end{array}$ \\
\hline $\begin{array}{l}\text { V: spent } \\
\text { Fig. } 2(\mathrm{~F}, \mathrm{I})\end{array}$ & $\begin{array}{l}\text { - In males, the majority of follicles are } \\
\text { empty } \\
\text { - Few unspawned oocytes with some } \\
\text { follicles lacking sex cells } \\
\text { - Follicles collapse and degenerate } \\
\text { - Cellular waste observed in some cells }\end{array}$ \\
\hline
\end{tabular}
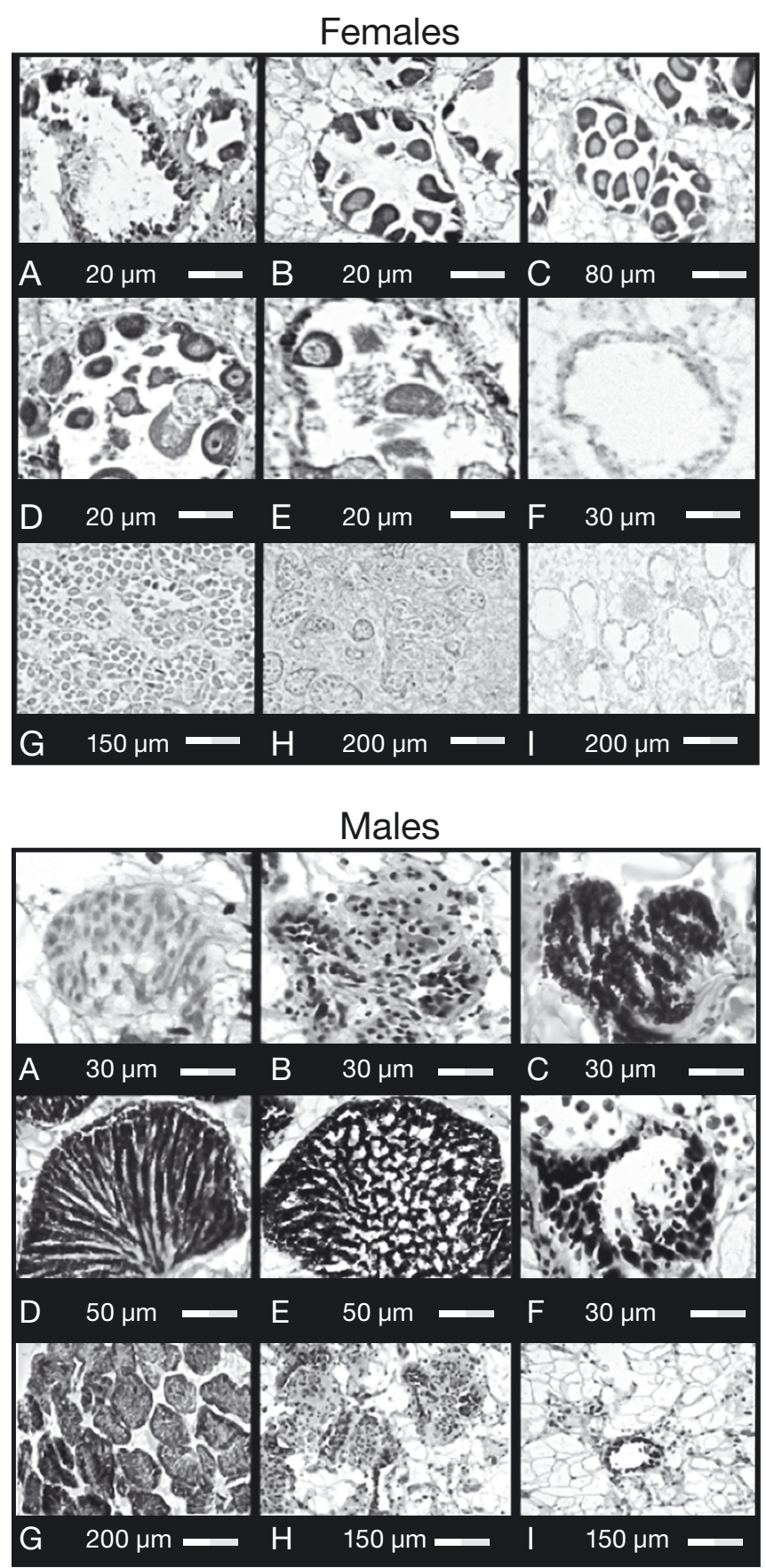

Fig. 2. Seasonal gametogenesis of female and male ribbed mussels Geukensia granosissima. Reproductive stages were classified as in Brousseau (1982): Stage I = indifferent (not shown), (A,B) Stage II = developing, (C,D) Stage III = mature, (E) Stage IV = partially or post-spawned, (F) Stage V = spent. The morphology and density of gametes was considered, ranging from $(\mathrm{G})$ ripe to $(\mathrm{H})$ spawning and (I) spent. $(\mathrm{D}, \mathrm{E})$ Note linear removal of spermatocytes from aggregates and egg wasting and $(\mathrm{H})$ aggregate disintegration and transport of gametes during spawning. Reproductive stages were determined through histological preparations of visceral mass and mantle tissues sampled from ribbed mussels collected from Cocodrie and Raccoon Lake, LA, USA, in 2011 and 2012. Note differences in scale 
tion. Progression of gametogenesis was then compared by site and sex and related to patterns of temperature and salinity.

\section{RESULTS}

\section{Environmental characteristics}

Water temperature was similar among study sites, ranging from a low of 5.2 to a high of $32.8^{\circ} \mathrm{C}$ during 2011-2012 (Fig. 3). Salinity differed significantly between sites with lower salinity at Cocodrie (mean \pm SE: $6.7 \pm 0.3$; range: $1.5-17.3$ ) as compared to Raccoon Lake (mean \pm SE: $17.2 \pm 0.3$; range: $3.2-32.6$ ). Water elevation was similar through the years at both sites.

\section{Patterns of site and seasonal gametogenesis}

In total, 317 mussels were analyzed, of which 115 were males, and 127 were females, and the remainder of indeterminate sex (Table 2). Mean size of sampled mussels ranged from $69.9 \pm 1.3 \mathrm{~mm}$ (mean $\pm \mathrm{SE}$ ) at Raccoon Lake to $54.1 \pm 1.8 \mathrm{~mm}($ mean $\pm \mathrm{SE})$ at Cocodrie.

Patterns of gametogenesis varied between sites and by sex (Fig. 4). Individuals of indeterminate sex are Stage I mussels (not shown in Fig. 4) and occurred in December and January at both sites (mean temperature $\pm \mathrm{SE}: 13.8 \pm 0.4$; range $10.2-22.1^{\circ} \mathrm{C}$ ) and in February at the low salinity site. Temperatures first exceeded $20^{\circ} \mathrm{C}$ on January 27 but did not remain above $20^{\circ} \mathrm{C}$ until the end of February. At the high
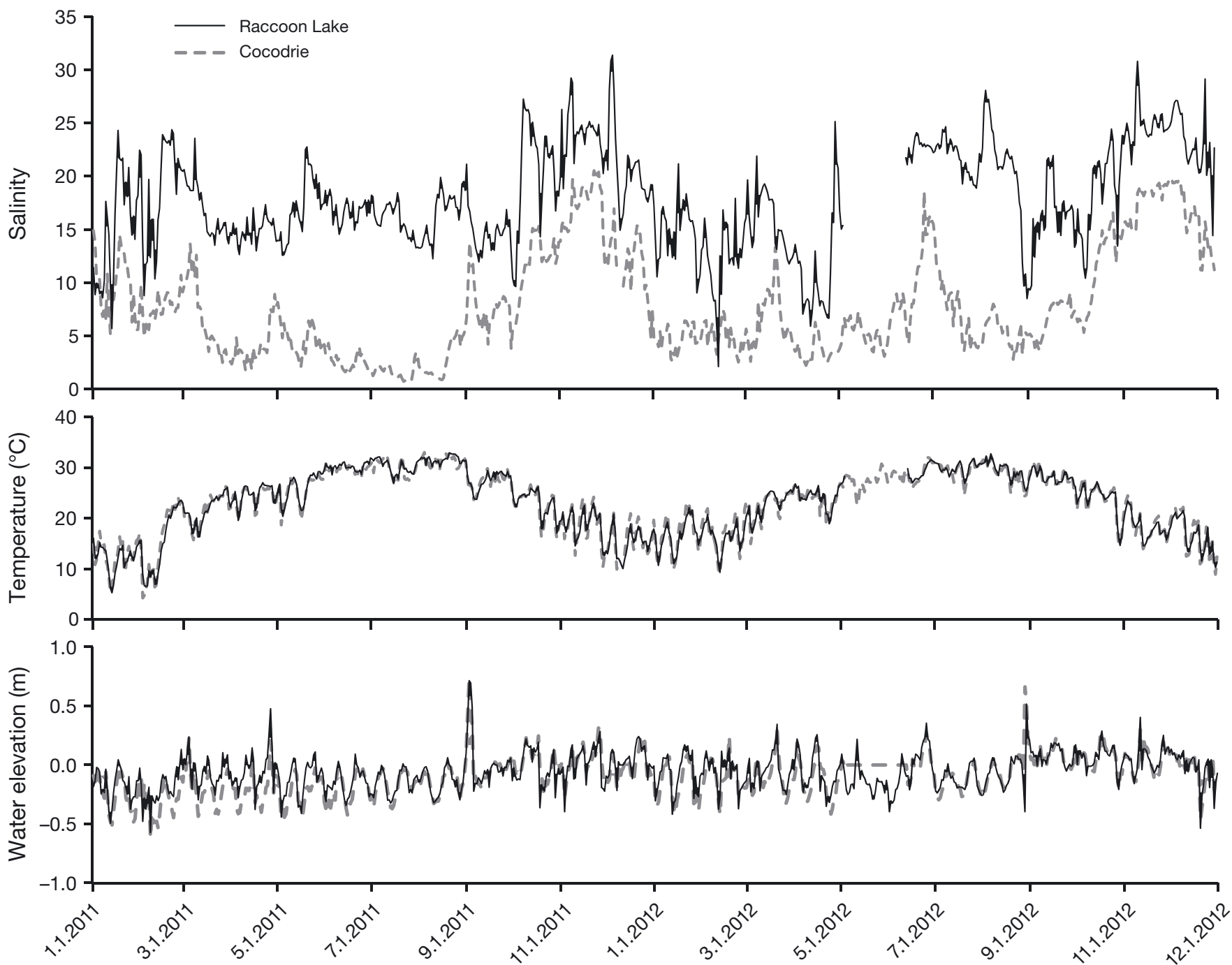

Fig. 3. Daily (A) salinity, (B) temperature $\left({ }^{\circ} \mathrm{C}\right)$, and (C) water level (m) at Raccoon Lake and Cocodrie, LA, USA, $2011-2012$. Data were taken from hourly measurements recorded at USGS Coastwide Reference Monitoring System stations CRMS0178 and CRMS0369. Dates are given as mo.d.yr 
Table 2. Geukensia granosissima. Number of mussels by sex used for histological analysis each month. Indet.: indeterminate

\begin{tabular}{|c|c|c|c|c|c|c|}
\hline & \multirow{2}{*}{ Indet. (n) } & \multicolumn{2}{|c|}{ Cocodrie } & \multicolumn{3}{|c|}{ Raccoon Lake } \\
\hline & & Female (n) & Male (n) & Indet. (n) & Female (n) & Male (n) \\
\hline Jan & 10 & 0 & 0 & 10 & 0 & 0 \\
\hline Feb & 10 & 0 & 0 & 7 & 2 & 1 \\
\hline Mar & 2 & 3 & 5 & 0 & 4 & 6 \\
\hline Apr & 0 & 6 & 4 & 0 & 8 & 2 \\
\hline May & 0 & 3 & 7 & 0 & 4 & 6 \\
\hline Jun & 0 & 5 & 5 & 0 & 5 & 5 \\
\hline Jul & 1 & 13 & 12 & 0 & 6 & 4 \\
\hline Aug & 1 & 12 & 7 & 0 & 10 & 10 \\
\hline Sep & 0 & 11 & 9 & 0 & 13 & 8 \\
\hline Oct & 4 & 9 & 7 & 5 & 8 & 7 \\
\hline Nov & 4 & 2 & 4 & 1 & 3 & 6 \\
\hline Dec & 10 & 0 & 0 & 10 & 0 & 0 \\
\hline
\end{tabular}

salinity site, progression of gametogenesis extended from February through November, with mussels at the high salinity site developing in February (Stage II), and some mussel maturity (Stage III) beginning in March. Mature gonads were detected from March through October (mean temperature \pm SE: $28.4 \pm$ $2.1^{\circ} \mathrm{C}_{i}$ mean salinity $\pm \mathrm{SE}: 18.5 \pm 3.4$ ). In contrast, at the low salinity site, progression of gametogenesis extended only from March through November, with development (Stage II) not evident until March, and mussel maturity (Stage III) not occurring until April. Mature gonads were detected at the low salinity site from April through November (mean temperature $\pm \mathrm{SE}: 28.6 \pm 2.3^{\circ} \mathrm{C}_{i}$ mean salinity $\pm \mathrm{SE}: 5.7 \pm 2.1$.

Interestingly, there was also a clear difference in patterns between males and females, with female mussels not reaching Stage III (mature) until June, several months after male mussels had ripe gonads (Fig. 4); furthermore, low salinity females had lower percent maturation compared to high salinity females.

\section{DISCUSSION}

During this study, progression of gametogenesis in the ribbed mussel was recorded for 9 mo of the year, from late spring, when temperatures rose above $20^{\circ} \mathrm{C}$, and continued through early fall, when temperatures dropped below $20^{\circ} \mathrm{C}$. Furthermore, salinity appears to modulate progression of gametogenesis as evidenced by differences in maturation dates and extent of maturation between low and high salinity

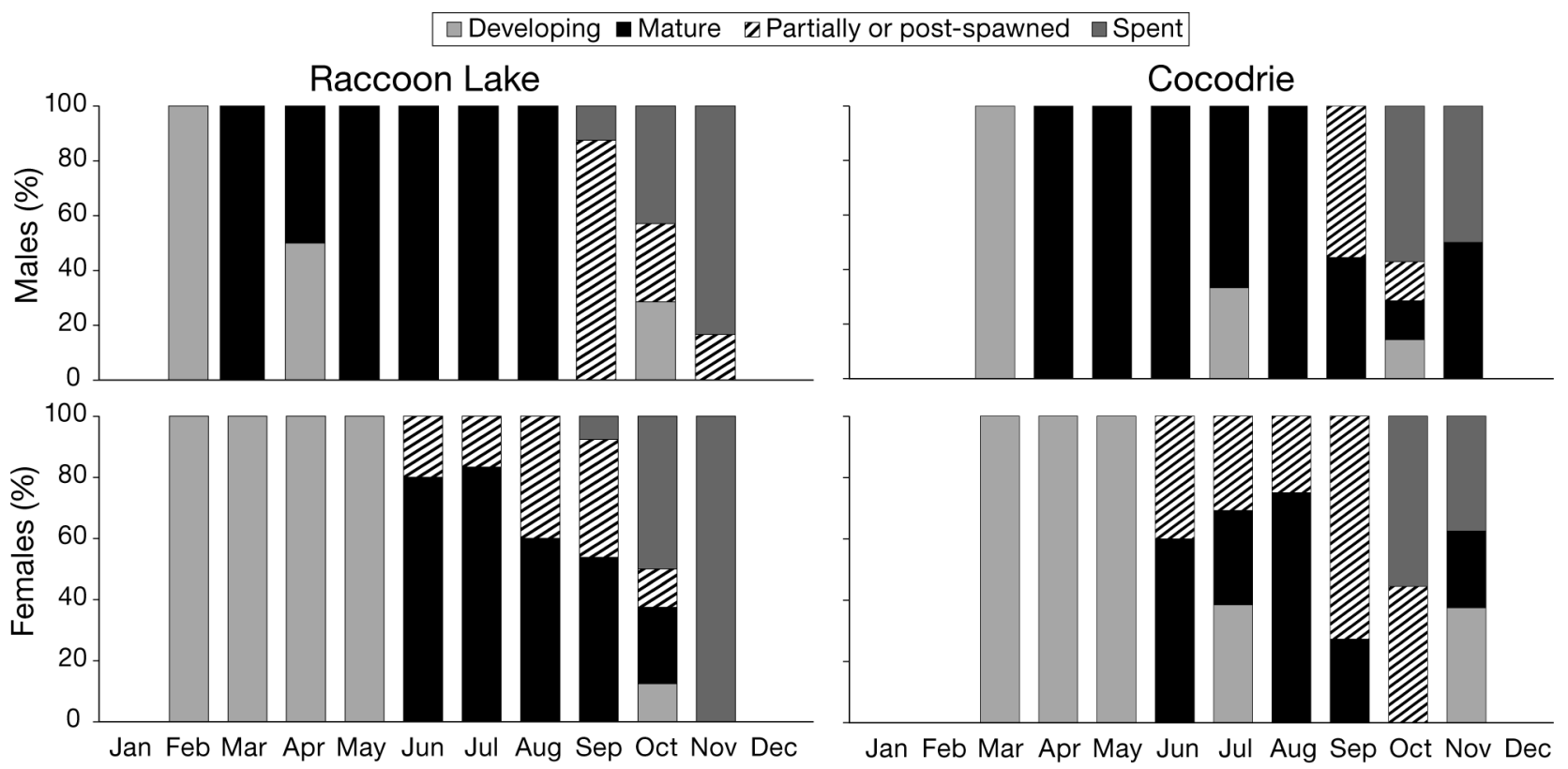

Fig. 4. Seasonal gametogenesis of female and male ribbed mussels Geukensia granosissima at Cocodrie and Raccoon Lake, LA, USA. Gametogenic stages were classified as Stage I (indifferent), Stage II (developing), Stage III (mature), Stage IV (partially or post-spawned) and Stage V (spent) through histological preparations of visceral mass and mantle tissues sampled monthly from ribbed mussels collected randomly at Cocodrie and Raccoon Lake. Data are from July 2011 to October 2012 ; for July through October, data from 2011 and 2012 are combined for each month and sex. January and December have no data as 
sites. These findings coincide with those of Ruiz et al. (1998) and Baez et al. (2005), who reported that bivalve mollusks in tropical areas tend to have prolonged spawning, likely associated with extended warm temperatures, but that salinity may affect the timing and extent of gametogenesis. In this sub-tropical area, mussels in the lower salinity site, Cocodrie, exhibited a delay in the onset of reproductive maturity despite similar temperature regimes. Results indicate that in this region, both temperature and salinity can profoundly influence gametogenesis. Differences in timing and peak maturity between our sites, which had similar daily temperatures, indicate that changing salinity regimes will impact ribbed mussel reproduction, potentially affecting population dynamics of a key benthic bivalve in this region.

The effects of increased temperatures on reproductive development are well documented in both wild and hatchery-raised populations of several mussel species (Brousseau 1982, Hilbish 1987). Sexual maturation and spawning along the Atlantic coast generally take place as temperatures warm, from mid-spring through late summer (McDougall 1943, Kuenzler 1961, Brousseau 1982, Jordan \& Valiela 1982, Franz 1996). In the present study, this pattern is similar, with gametogenesis occurring at both sites as water temperatures rose above $20^{\circ} \mathrm{C}$. Such patterns of gametogenesis may be a result of increased metabolic activity and increased carbon investment within reproductive tissues as temperatures increase (Barber \& Blake 1983). Furthermore, progression of gametogenesis associated with elevated temperatures could help to ensure optimal environmental conditions for vulnerable mussel larvae (Sprung 1984, Widdows 1991). For example, as temperatures warm, food resources may become more available through faster decomposition rates and provision of detrital resources from emergent marsh plant species, which have been found to supply over $50 \%$ of ribbed mussel diets in New England marshes (Jordan \& Valiela 1982, Langdon \& Newell 1990) and in subtropical estuarine salt marshes. Both the low and high salinity sites were part of healthy productive marshes but with differences in dominant vegetative species due to the different salinity regimes; there is no information, however, on the relative food value of these different vegetative species (i.e. Spartina patens versus $S$. alterniflora). Furthermore, assuming food resources were equivalent, both sites experienced similar flooding regimes and had equal access to detrital resources; flooding regime has been associated with differences in growth rates and mortality due to access to detrital resources (Jordan \& Valiela 1982).
While temperature appears to have a dominant effect controlling the time of year in which reproductive development occurs, observed differences between sites occurred that may be partially explained by other environmental stimuli. At our study sites, maturation of gonads was associated with a drop in salinity, which occurred 1 mo later at the lower salinity site. Specifically, at Raccoon Lake, salinity fell from 15 to below 10 in February, with gonad ripening beginning in March, while at Cocodrie, salinity dropped from about 10 to 4 in March, with the onset of gonad ripening occurring in April. This finding is similar to that reported for ribbed mussels in tropical marshes experiencing minimal seasonal temperature variation, where it was found that periods of spawning were associated with drops in salinity in midsummer and late fall associated with shifts between dry and wet seasons (Baez et al. 2005). Similar coincidence of spawning and salinity fluctuations has been found in several other tropical molluscan species (Velez 1976, Puyana 1995).

Marsh flooding, temperature and salinity have all been suggested as important direct determinants of mussel gametogenesis by regulating seasonal metabolic activity (Dominguez et al. 2010). In the present study, both sites experienced similar flooding and temperature regimes (Fig. 4) but differed in salinity regimes. As lower salinity significantly reduces growth rates (Honig 2013), age and mussel size are possible confounding factors in interpreting the results. However, once sexually mature (>20 mm shell length; Borrero 1987, Franz 1996), mussels are known to be synchronous spawners, and size or agerelated effects on gametogenic progression would be detrimental to population sustainability. In an agerelated study of the bivalve Mysella bidentata, it was found that temporal differences in the reproductive cycle occurred, but only in Year $1 \mathrm{M}$. bidentata (O'Brien \& Keegan 2006). It is more likely that differences in gametogenic timing were related to other environmental stimuli, such as salinity, rather than size or age of the mussels assessed.

Interestingly, there were distinct and consistent differences in progression of gametogenesis between male and female mussels at both sites in our study. Male mussels reached sexual maturity earlier than female mussels. Early male reproductive development has been previously observed in several ribbed mussel populations along the temperate and subtropical Atlantic coast and has been suggested as a potential strategy to ensure maximum opportunity for fertilization (Kuenzler 1961, Brousseau 1982, Jordan \& Valiela 1982, Baez et al. 2005). This has also 
been observed in other bivalve species (Toro et al. 2002, Mladineo et al. 2007).

The anticipated increases in ambient temperature, salinity, and relative sea level along the northern coast of the Gulf of Mexico may significantly alter the timing, duration, and reproductive output of gametogenesis in ribbed mussels. Results from this study suggest that both increases in temperature and relative marsh flooding rate may lengthen the reproductive season, approximating the year-round reproductive activity observed in tropical marshes (Baez et al. 2005). Consequently, as temperatures become consistently warm, seasonal changes in salinity may play a larger role in promoting early gonadal development. Furthermore, continued efforts to increase freshwater flow into Louisiana estuaries that lower salinity during the onset of gametogenesis (February-March) may alter the timing and extent of mussel gametogenesis in affected areas. Greatly reduced salinities during spring diversion events, and increased salinities in the late summer and fall due to land loss and Gulf thermal expansion (Walker et al. 2005), may significantly affect gametogenic timing and reproductive output of ribbed mussels in southeastern Louisiana. As ribbed mussels are a key benthic intertidal bivalve in this region, understanding how predicted changes in salinity and temperature regimes affect ribbed mussel populations is critical to understanding potential ecosystem changes.

Acknowledgements. A special thanks to Jerome La Peyre, Sandra Casas and Cheryl Crowder for their critical help in histological tissue processing. Thanks also to Jerome La Peyre for comments on an earlier draft that significantly improved this manuscript. We also thank Bran Wagner, Nathan Yeldell, Molly Rybovich, Shea Miller, Lindsay Schwarting, Erin Leonhardt, Justin Leonhardt, Lisa Borrassa, James Ialeggio, and Clayton Kern for their assistance in the field and in the laboratory. We thank R. Eugene Turner and Robert Romaire for comments on early versions of this work. Any use of trade, firm, or product names is for descriptive purposes only and does not imply endorsement by the US Government.

\section{LITERATURE CITED}

Baez M, Severeyn Y, Severeyn H (2005) Ciclo reproductivo de Geukensia demissa (Bivalvia: Mytilidae) en la playa de Nazaret, El Mojan, Estado Zulia, Venezuela. Cienc Mar 31:111-118

> Barber BJ, Blake J (1983) Growth and reproduction of the bay scallop, Argopecten irradians (Lamarck) at its southern distributional limit. J Exp Mar Biol Ecol 66:247-256

Beukema JJ, Dekker R (2007) Variability in annual recruitment success as a determinant of long-term and largescale variation in annual production of intertidal Wadden
Sea mussels (Mytilus edulis). Helgol Mar Res 61:71-86

$>$ Borrero F (1987) Tidal height and gametogenesis: reproductive variation among populations of Geukensia demissa. Biol Bull 173:160-168

Brousseau D (1982) Gametogenesis and spawning in a population of Geukensia demissa (Pelecypoda: Mytilidae) from Westport, Connecticut. Veliger 24:247-251

Cerwonka RH (1968) Population structure and filtering characteristics of Modiolus demissus in a Connecticut estuary. PhD thesis, University of Connecticut, Storrs, CN

Dominguez L, Villalba A, Fuentes J (2010) Effects of photoperiod and the duration of conditioning on gametogenesis and spawning of the mussel Mytlius galloprovincialis (Lamarck). Aquac Res 41:e807-e818

> Feng Z, Li C (2010) Cold-front-induced flushing of the Louisiana bays. J Mar Syst 82:252-264

Franz D (1996) Size and age at first reproduction of the ribbed mussel Geukensia demissa (Dillwyn) in relation to shore level in a New York salt marsh. J Exp Mar Biol Ecol 205:1-13

Franz D (1997) Resource allocation in the intertidal saltmarsh mussel Geukensia demissa in relation to shore level. Estuaries 20:134-148

Hackney JT (1983) A note on the reproductive season of the Carolina marsh clam Polymesoda caroliniana (Bosc) in an irregularly flooded Mississippi marsh. Gulf Res Rep 7: 281-284

> Hilbish TJ (1987) Response of aquatic and aerial metabolic rates of the ribbed mussel Geukensia demissa (Dillwyn) to acute and prolonged changes in temperature. J Exp Mar Biol Ecol 105:207-218

Honig A (2013) Population ecology of the ribbed mussel in southeastern Louisiana. MS thesis, Louisiana State University, Baton Rouge, LA

> Inoue M, Park D, Justic D, Wiseman W Jr (2008) A high-resolution integrated hydrology-hydrodynamic model of the Barataria Basin system. Environ Model Softw 23: 1122-1132

Jordan TE, Valiela I (1982) A nitrogen budget of the ribbed mussel, Geukensia demissa, and its significance in nitrogen flow in a New England salt marsh. Limnol Oceanogr 27:75-90

- Knights AM, Walters K (2010) Recruit-recruit interactions, density-dependent processes and population persistence in the eastern oyster Crassostrea virginica. Mar Ecol Prog Ser 404:79-90

> Kuenzler EJ (1961) Structure and energy flow of a mussel population in a Georgia salt marsh. Limnol Oceanogr 6: 191-204

> Langdon CJ, Newell RIE (1990) Utilization of detritus and bacteria as food sources by two bivalve suspension-feeders, the oyster Crassostrea virginica and the mussel Geukensia demissa. Mar Ecol Prog Ser 58:299-310

Lee T, Foighil DO (2004) Hidden Floridian biodiversity: mitochondrial and nuclear gene trees reveal four cryptic species within the scorched mussel, Brachidontes exustus, species complex. Mol Ecol 13:3527-3542

> Lee T, Foighil DO (2005) Placing the Floridian marine genetic disjunction into a regional evolutionary context using the scorched mussel, Brachidontes exustus, species complex. Evolution 59:2139-2158

LOCPR (Louisiana Office of Coastal Protection and Restoration) (2012) Coastwide Reference Monitoring SystemWetlands Monitoring Data. Retrieved from Strategic Online Natural Resource Information System (SONRIS) 
database. http://coastal.louisiana.gov/index.cfm?md= pagebuilder\&tmp $=$ home\&pid=92 (accessed 1 August 2012)

McDougall KD (1943) Sessile marine invertebrates of Beaufort, North Carolina. Ecol Monogr 13:321-374

Mladineo I, Peharda M, Orhanovic S, Bolotin J, Vrancic MP, Treursic B (2007) The reproductive cycle, condition index and biochemical composition of the horse-bearded mussel Modiolus barbatus. Helgol Mar Res 61:183-192

O'Brien K, Keegan BF (2006) Age-related reproductive biology of the bivalve Mysella bidentata (Montagu) (Bivalvia: Galeommatacea) in Kinsale Harbour (south coast of Ireland). Ir Nat J 28:284-299

Palmer MA (1980) Variation in life-history patterns between intertidal and subtidal populations of the meiobenthic copepod Microarthridion littoraie. Mar Biol 60:159-165

Puyana M (1995) Aspectos biologicos y ecologicos de Mytilopsis sallei (Recluz, 1849)(Bivalvia: Dreissenidae) en bancos de ostras de la Cienaga Grande de Santa Marta, Caribe Colombiano. Biol Inst Inves Mar Punta Betin 24:39-53

Ruiz E, Cabrera J, Cruz R, Palacios J (1998) Crecimiento y ciclo reproductivo de Polymesoda radiata (Bivalvia:

Editorial responsibility: Yoichi Yusa,

Nara, Japan
Corbiculidae) en Costa Rica. Rev Biol Trop 46:643-648

Sprung M (1984) Physiological energetics of mussel larvae (Mytlus edulis). II. Food uptake. Mar Ecol Prog Ser 17: 295-305

Toro JE, Thompson RJ, Innez DJ (2002) Reproductive isolation and reproductive output in two sympatric mussel species (Mytilus edulis, M. trossulus) and their hybrids from Newfoundland. Mar Biol 141:897-909

Velez A (1976) Credimiento, edad y madurez sexual del ostion Crassostrea rhizophorae de Bahia de Mochima. Bol Inst Oceanogr 15:65-72

- Walker ND, Wiseman WJ, Rouse L, Babin A (2005) Effects of river discharge, wind stress, and slope eddies on circulation of the Mississippi River plume. J Coast Res 21: 1228-1244

Whitton T, Jenkins S, Richardson C, Hiddink J (2012) Aggregated prey and predation rates: juvenile shore crabs (Carcinus maenas) foraging on post-larval cockles (Cerastoderma edule). J Exp Mar Biol Ecol 432:29-36

Widdows J (1991) Physiological ecology of mussel larvae. Aquaculture 94:147-163

Wiseman WJ Jr, Swenson EM, Power J (1990) Salinity trends in Louisiana estuaries. Estuaries 13:265-271

Submitted: January 8, 2014; Accepted: September 15, 2014 Proofs received from author(s): October 12, 2014 